\title{
Greenhouse gas inventory of a state water and wastewater utility in Northeast Brazil
}

\author{
J.O. Santos ${ }^{a,}{ }^{*}$, J.C.S. Andrade ${ }^{b}$, M.M.O. Marinho ${ }^{c}$, A. Noyola ${ }^{\text {d }}$, L.P. Güereca ${ }^{\mathrm{d}}$ \\ ${ }^{a}$ Industrial Engineering Program at the Federal University of Bahia, Polytechnic School, Rua Aristides Novis, $n^{\circ} 2,6$ th floor - Federação, EP-UFBA, \\ 40.210-630, Salvador, Bahia, Brazil \\ ${ }^{\mathrm{b}}$ School of Administration at the Federal University of Bahia, Brazil \\ ${ }^{\mathrm{c}}$ Department of Environmental Engineering at the Federal University of Bahia, Brazil \\ d Instituto de Ingeniería, Universidad Nacional Autónoma de Mexico (UNAM), Mexico
}

\section{A R T I C L E I N F O}

\section{Article history:}

Received 25 April 2014

Received in revised form

8 February 2015

Accepted 30 March 2015

Available online 8 April 2015

\section{Keywords:}

Carbon footprint

Brazil

GHG emissions inventory

Water and wastewater company

\begin{abstract}
A B S T R A C T
The growing concern about climate change and related greenhouse gas emissions (GHG) has been shared by many companies who are now involved in emission reduction efforts. In order to do this, it is necessary to first develop GHG emission inventories. The construction of inventories is not common practice in developing countries and among Brazilian water and wastewater companies, only four companies, among the top 25, have developed their GHG inventories, and none in the Northeast of the country. This paper aims to identify and estimate GHG emissions from the activities of a water utility, Empresa Baiana de Águas e Saneamento S.A (Embasa) in the State of Bahia during 2012. The method used for the inventory was the GHG Protocol proposed by World Business Council for Sustainable Development (WBCSD) and World Resources Institute (WRI), the most widely adopted method worldwide. In addition, the guidelines of IPPC (Intergovernmental Panel on Climate Change) were used to calculate emissions from wastewater treatment plants. It was found that the emissions resulting from sewage treatment (mostly carried out by anaerobic processes) constitute the largest source of GHG at the sanitation company studied, when considering the activities defined in this work. The assessment of GHG sources and emissions identified in this research can support proposals for reduction targets and benchmarking. The results form the basis for the incorporation of GHG reduction measures in the company's strategic planning as well as for integrating its sustainability report. The findings of this work can also help other companies to undertake GHG reduction measures.
\end{abstract}

() 2015 Elsevier Ltd. All rights reserved.

\section{Introduction}

Growing concern about climate change and its causes have led national governments to establish policies and strategies to control greenhouse gas emissions (GHG). As a result, many organizations are taking measures in this direction as part of their corporate sustainability objectives. A basic step is to identify and quantify the main sources of GHG in order to take effective measures for their reduction. These corporate activities are often referred to as the carbon accountability of an organization (Ascui and Lovell, 2012; Schaalteger and Csutora, M, 2012; Stechemesser and Guenther, 2012).

\footnotetext{
* Corresponding author.

E-mail addresses: jamiles@ufba.br (J.O. Santos), noyola@pumas.ii.unam.mx (A. Noyola).
}

Preparing an inventory is the most commonly used tool to quantify GHG emissions from an organization. A GHG inventory accounts for the emissions from all of the sources identified in the direct and indirect activities associated to a company. One of the most commonly used methods today is the GHG Protocol Corporate Accounting and Reporting Standard (WBCSD/WRI, 2004). This guide provides information on preparing GHG inventories, which is now widely used by many companies and environmental organizations around the world. The gases considered within its scope are those listed in the Kyoto Protocol (carbon dioxide, methane, nitrous oxide, hydrofluorocarbons, perfluorocarbons and sulfur hexafluoride). The method is compatible with the ISO standards (ISO, 2006) and the Intergovernmental Panel on Climate Change (IPCC, 2006) methods.

Another method which could be used as a reference when preparing an inventory is ISO 14064-1, which guides the adoption 
of measures aiming to reducing or eliminating potential emission sources.

With a more wide-ranging vision, Galli et al. (2012) define the footprint family as a set of indicators which aim to track human pressure on the planet in accordance with specific aspects under analysis. They consider a joint analysis of the ecological, water and carbon footprints. The authors highlight that the carbon footprint measures the total GHG emissions originating directly and indirectly from an activity or stages of a product's life cycle.

Although Brazil does not have compulsory goals, in 2009 it voluntarily established a reduction in its emissions of between $36.1 \%$ and $38.9 \%$ by 2020 , as contained in the Plan and National Law for Climate Changes and Federal Law 12.187 of December 29, 2009. In a number of States in Brazil, such as São Paulo and Rio de Janeiro (Environmental Company of the State of São Paulo-CETESB, 2012; Institute for the Environment of Rio de Janeiro-INEA, 2012), a GHG inventory has now become a regulatory requirement for environmental permits, demonstrating the importance of this issue.

In other countries, various sectors are preparing inventories and proposing measures in order to contribute to reduction targets. Among the most active is the education sector, with several publications (Alvarez et al., 2014; Klein-Banai and Theis, 2013; Güereca et al., 2013; Larsen et al., 2013; Li, X et al., 2015; Ozawa-Meida et al., 2013) followed by others on the carbon footprints of nations (Hertwich and Peters, 2009; Wiedmann et al., 2010), cities (Larsen and Hertwich, 2010) and other sectors (Figueiredo et al., 2013; Vázquez- Rowe et al., 2013; Zakkour et al., 2014; Zhai et al., 2014).

Water and wastewater treatment produces a significant amount of methane and nitrous oxide, so reducing these emissions is one of the principal challenges for sanitation companies facing climate change issues (Gupta and Singh, 2012).

In developed countries, where the energy source is basically made up of fossil fuels, there is concern about the consumption of energy in the water sector, as it constitutes the largest emission source (Barber, 2009). A number of articles discuss the correlation between energy consumption and the carbon footprint (Boulos and Bros, 2010) that a significant percentage of this energy is used for pumping.

There are still very few articles in the literature on the carbon footprint of water and sanitation companies. The papers focusing on climate change and wastewater management are directed towards quantifying the emissions resulting from municipal wastewater collection systems (Guisasola et al., 2008), or from sludge treatment (Uggetti et al., 2012), emissions analysis according to the typology adopted (Cakir and Stenstrom, 2005; Shahabadi et al., 2009), modeling emissions at treatment plants, especially methane (Guisasola et al., 2009; Foley et al., 2009) and nitrous oxide (Foley et al., 2010; Law et al., 2012; Daelman et al., 2013) and measuring methane emissions (Wang et al., 2011). Very few articles include activities which are related to scope 3 (Frijns, 2011).

However, some companies are preparing and publishing their greenhouse gas inventories in Brazil. Twenty-two inventories were published in 2008, the first year that the Brazilian GHG Protocol program (GHG Protocol, 2010) was introduced. On consulting the GHG Protocol site, it can be seen that SANEPAR (the water and wastewater company of the State of Parana) is the only sanitation company that publishes an inventory in the Brazilian Public Emissions Register in 2012. As indicated by Perini (2011), Companhia de Agua e Esgoto de Ceará - CAGECE has also been developing initiatives related to climate change through measures directed towards mitigating greenhouse gas emissions. The practice of preparing inventories is still uncommon among water and wastewater companies in Brazil. At present, only 4 companies, Companhia Espírito Santense de Saneamento -
CESAN (Girondolli, 2009), Companhia de Saneamento de Minas Gerais (Sanitation Company in the State of Minas Gerais) COPASA (Rennó, 2011), Companhia de Saneamento do Paraná SANEPAR (Sanepar, 2010) and Companhia de Saneamento Básico no Estado de São Paulo S.A (Basic Sanitation Company in the State of São Paulo), SABESP (Sabesp, 2007), which are among the top 25 water utilities in Brazil, have developed inventories. However, little information is given in their corporate reports about the implementation of strategies to mitigate their GHG emissions. In addition, none of these companies are from the northeast region of the country.

In his study about carbon footprint of the water sector in Holland, Frijns (2011) used the UK Water Industry Research (UKWIR) guidelines as a reference. UKWIR has been developing research to provide guidelines in order to aid in the quantification and publication of GHG emissions in companies in the water industry. This method used was also applied by Barber (2009) to evaluate the carbon footprint of sewage sludge digestion.

This paper aims to identify and evaluate GHG emissions generated from the activities of a water and wastewater company, Empresa Baiana de Águas e Saneamento S.A (Embasa) in the State of Bahia, during 2012. It also contributes with data to the few experiences in preparing GHG inventories and public reports in water utilities in Brazil.

\section{Method}

The inventory was carried out considering Embasa's area of coverage. The company comprises seven directorates: three Operation and Expansion Directorates (Metropolitan Region of Salvador (MRS), North and South), the Technical and Sustainability Directorate, Financial and Commercial Directorate, Corporate Management Directorate and the Presidency. The administration is decentralized: 13 regional units in the countryside and 6 in the Metropolitan Region of Salvador (Embasa, 2012). According to Embasa (2012), the company operates in 362 municipalities of the 417 located in the State of Bahia, resulting in 410 water supply systems (106 integrated and 304 local) and 73 sanitary waste systems. In the year that this inventory was carried out, the company had 5765 employees working in the various units. Fig. 1 shows Embasa's regional units.

The method selected for this inventory is based on the GHG protocol (WRI/WBCSD, 2004) and IPCC Guidelines for National Greenhouse Gas Inventories (IPCC, 2006) on direct emissions from wastewater treatment.

\subsection{Applying the greenhouse gas protocol (GHG protocol)}

The GHG Protocol establishes three scopes for executing inventories. Scope 1 refers to direct emissions from the company's processes; scope 2 includes indirect emissions resulting from energy consumption and scope 3 includes emissions from activities over which the company has no control of the sources, such as transportation.

Following the definition of the emission sources to be analyzed, the gathering of data from the selected activities was carried out. The company's organizational structure was taken into consideration, with a view to identifying the offices responsible for collecting the required information on the emission source. Visits were made to the various company units between June 2012 and October 2013, where a wide range of documents were obtained (reports, database, etc.) and interviews were held with key personnel.

Then the macro processes carried out by the company were analyzed and following the guidelines for identifying potential 


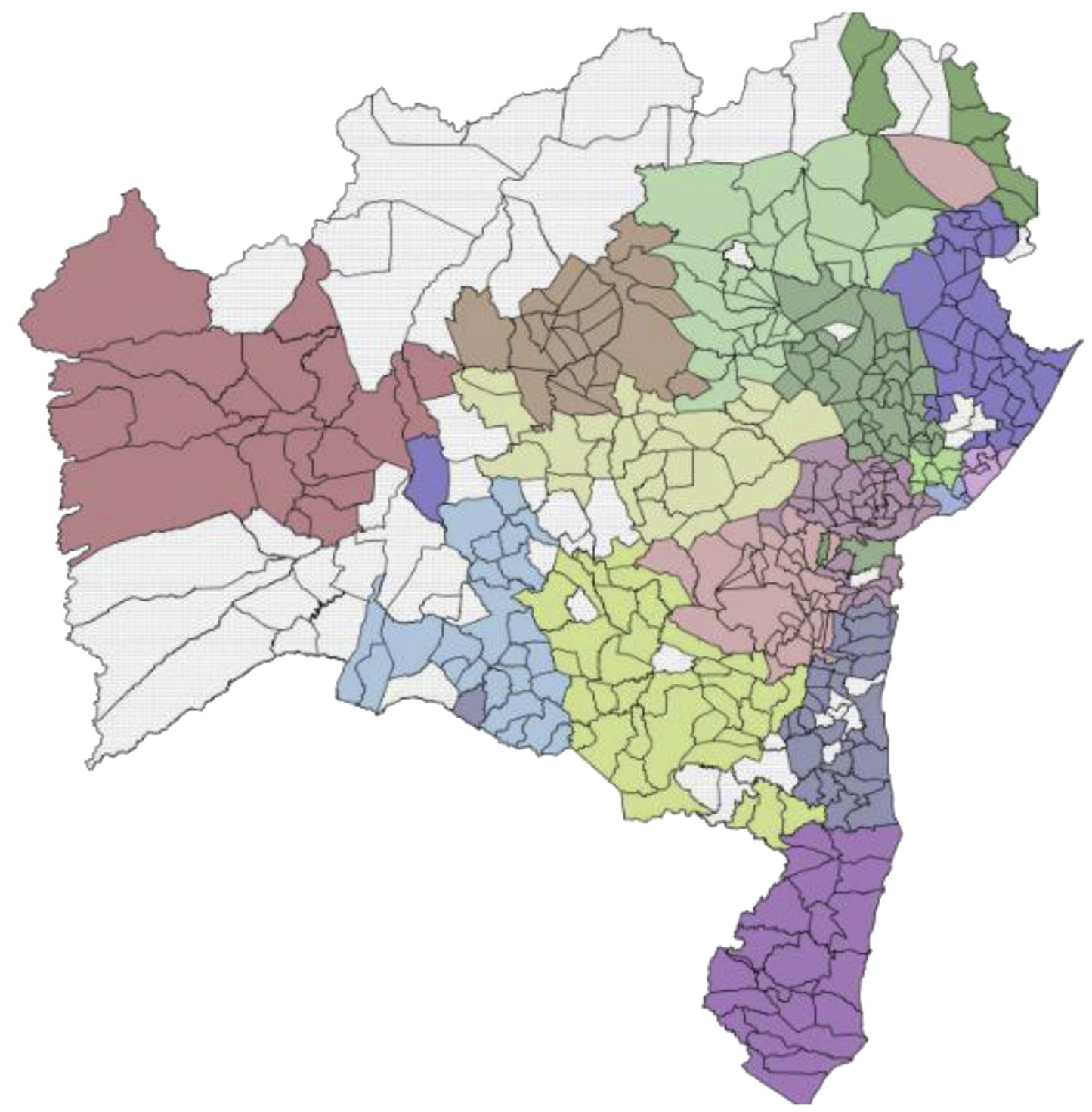

\section{Alagoinhas}

Barreiras

$\square$ Feira de Santana

$\square$ Irecé

Itaberaba

\section{Paulo Afonso}

Senhor do Bonfim

\section{Caetité}

\section{Itabuna}

$\square$ Itamaraju

$\square$ Jequié

Santo Antônio de Jesus

$\square$ Vitória da Conquista $\square$ Camaçari

\section{Candeias}

UMB/UMF/UMJ/UML

Fig. 1. Regional units

sources of GHG emissions in the water and wastewater sector the following scope categories were defined and calculated (Table 1):

The emissions for a one year period (January 2012 to December 2012) were calculated for this paper.

Scope 1. Direct emissions from wastewater treatment plants (WWTP).-The steps for calculating $\mathrm{CH}_{4}$ emissions from wastewater treatment facilities followed the IPCC Guidelines for National Greenhouse Gas Inventories, 2006)

Step 1: An estimate of organically degradable material in domestic wastewater is shown in Table 2.

$\mathrm{TOW}=\mathrm{P} \times \mathrm{BOD} \times 0.001 \times 365$ 
Table 1

Emission types and sources considered in the inventory.

\begin{tabular}{lll}
\hline Emission type & Activity & Description \\
\hline Scope 1 & Wastewater treatment & $\mathrm{CH}_{4}$ emissions from WWTP and uncollected sewage \\
Direct emissions & Direct mobile combustion & Emissions from water catchment, \\
Scope 2 & Energy consumption & pumping raw water; \\
Indirect emissions & & pumping treated water; \\
& & pumping sewage and administrative activities \\
from home to work
\end{tabular}

where:

TOW = total organic load of wastewater in the year of the inventory, $\mathrm{kg}$ BOD/year.

$P=$ population in the year of the inventory.

$B O D$ (degradable organic component) $=$ BOD per capita in the year of the inventory, $\mathrm{g} /$ person/day (the standard amount for Brazil according to the IPCC-2006 Guide is 50 (g/person/day)

$0.001=$ conversion factor $(\mathrm{g}$ to $\mathrm{kg})$

$I=$ correction factor for industrial BOD disposal in the collection network (standard values: 1.25 for collected and 1 for uncollected).

Step 2: Organically degradable material entering the treatment plants was estimated based on the monitoring data listed in the Pollutant Load Declaration made available by the Department of Environmental Management of Embasa. Values for each month of 2012 were provided and the average annual BOD influent and effluent was therefore calculated. The BOD removed at the stations was calculated using the following equation:

$B O D r=(B O D$ entry $-B O D$ exit $) \times Q\left(\frac{l}{\text { day }}\right)$

where:

$\mathrm{BODr}=\mathrm{BOD}$ removed.

BOD entry $=$ BOD in the influent of wastewater treatment plants.

BOD exit $=$ BOD in the effluent of wastewater treatment plants.

The BOD discharged into the environment as raw sewage was calculated by subtracting the BOD entering the wastewater treatment plants (166,297,901.63 kgBOD/year) from the estimated total BOD produced by the served population (224,999,231.25 kgBOD/ year). This results in $58,701,329.62 \mathrm{kgBOD} /$ year discharged to natural receiving bodies.

This procedure resulted in the data presented in Table 3:

Step 3: The emission factor of a wastewater treatment system depends on its maximum potential of methane production and of the corrective factor, using the formula below:

$E F=B o \times M C f$

where:

EF: Emission Factor $\left(\mathrm{kgCH}_{4} / \mathrm{kgDBO}\right)$
Bo: Maximum $\mathrm{CH}_{4}$ production potential $\left(0.6 \mathrm{kgCH}_{4} / \mathrm{kgDBO}\right)$

MCF: $\mathrm{CH}_{4}$ corrective factor (IPCC proposed standard for each treatment system)

After applying the formula, the emission factor for each treatment system was found. This factor was then multiplied by the removed BOD. The result is found in $\mathrm{kgCH}_{4}$ then is converted in $\mathrm{tCO}_{2}$ eq. The Global Warming Power (GWP) for methane was 21.

Emissions from not removed BOD and the BOD discharged to the environment as raw sewage is considered in the estimate. Table 8 shows emission factors for each category.

Direct mobile combustion - Combustion emissions were estimated as follows:

\section{Combustion emissions $\mathrm{tCO}_{2} \mathrm{eq}=$ fuel consumption

$$
x \text { emission factor }
$$

Fuel consumption: Annual quantity of fuel consumed in 2012 in scope 1 activities, which was supplied by the Department of Transport of Embasa.

Emission factor for consumption by fuel type are based on the national land vehicle inventory prepared by the Ministry of the Environment in Brazil (MMA, 2011).

Scope 2. Energy consumption - indirect electricity emissions are estimated by multiplying the electricity consumption by the average electricity grid emission per month in Brazil.

\section{Electricity consumption emissions $\mathrm{tCO}_{2} \mathrm{eq}$}

$=$ Energy consumption per month $\times$ emission factor per month,

The emission factor for electrical energy is made available on a monthly basis by the Ministry of Science and Technology (Ministry of Science and Technology of Brazil, 2012).

Table 3

BOD values related to the WWTP in Bahia.

\begin{tabular}{ll}
\hline BOD & BOD removed (kg BOD/year) \\
\hline Entry to the plants & $166,297,901.63$ \\
Removed & $158,919,116.95$ \\
Not removed & $7,420,587.71$ \\
\hline
\end{tabular}

Table 2

Estimate of organically degradable material.

\begin{tabular}{|c|c|c|c|c|}
\hline \multirow[t]{2}{*}{ State } & A & $\mathrm{B}$ & $\mathrm{C}$ & $\mathrm{D}$ \\
\hline & Population & $\begin{array}{l}\text { Degradable organic component } \\
\text { (BOD) (kg BOD/cap/year) }\end{array}$ & $\begin{array}{l}\text { Correction factor for industrial BOD } \\
\text { discharged into sewers (I)2 }\end{array}$ & $\begin{array}{l}\text { Organically degradable material in } \\
\text { wastewater (TOW) (kg BOD/year) D = AXBXC }\end{array}$ \\
\hline Bahia & $12.328 .725^{\mathrm{a}}$ & 18.25 & $1^{\mathrm{b}}$ & $224,999,231.25$ \\
\hline
\end{tabular}


Table 4

Emissions factor and energy consumption.

\begin{tabular}{lll}
\hline Month & Emission factor $\left(\mathrm{tCO}_{2} / \mathrm{Mwh}\right)$ & Consumption $(\mathrm{Mwh})$ \\
\hline January & 0.0294 & 111782.5 \\
February & 0.0322 & 109153.4 \\
March & 0.0405 & 118471.9 \\
April & 0.0642 & 105526.2 \\
May & 0.062 & 119266.0 \\
June & 0.0522 & 109888.8 \\
July & 0.0394 & 107616.6 \\
August & 0.046 & 112361.4 \\
September & 0.0783 & 109748.2 \\
October & 0.0984 & 114941.0 \\
November & 0.1636 & 105890.1 \\
December & 0.1168 & 104984.8 \\
\hline
\end{tabular}

Table 5

Distance covered by employees and type of vehicle used (metropolitan area).

\begin{tabular}{lll}
\hline Vehicle & Distance $(\mathrm{km})$ & Plus $15 \%$ for lunch $(\mathrm{km})$ \\
\hline Car & $7,516,985$ & $8,644,532$ \\
Motorbike & $3,221,565$ & \\
Bus & $6,368,000$ & \\
\hline
\end{tabular}

Table 6

Distance travelled by employees not using public transport (countryside units).

\begin{tabular}{lll}
\hline & Extra 15\% & \\
\hline Distance by car (60\%) & $3,229,866$ & $3,714,345$ \\
Distance by motorbike (30\%) & $1,614,933$ & - \\
Distance on foot/by bicycle (10\%) & 538,311 & - \\
\hline
\end{tabular}

Table 8

Total emissions per source.

\begin{tabular}{llc}
\hline Category & Emissions $\left(\mathrm{tCO}_{2} \mathrm{eq}\right)$ & $\%$ \\
\hline Employee & 5658.28 & 0.58 \\
Energy consumption & $90,402.78$ & 9.35 \\
Direct mobile & 4970.86 & 0.51 \\
Business travel by air & 54.32 & 0.01 \\
Business land travel & 874 & 0.09 \\
Wastewater management & $865,426.92$ & 89.46 \\
Total & $\mathbf{9 6 7 , 3 8 7 . 1 6}$ & $\mathbf{1 0 0}$ \\
\hline
\end{tabular}

A calculation of the company's total consumption was made, based on both administrative and operational activities. Table 4 shows the emissions factor and consumption per month.

Scope 3. Business travel - An analysis of the distance covered during the year was required in order to estimate the emissions from business travel. Embasa does not register the distance travelled by employees on trips. Therefore, data from the daily control system, supplied by the financial execution division was used: information on the origin and destination of the journey, date and reason for the trip. The distance of each trip was then calculated using Google Maps, always considering the route covering the longest distance. The values obtained were then doubled to calculate the return journey. An estimate was made using the premise that the total distance covered was only made by one type of vehicle and also using the same type of fuel. The routes for air travel were classified as short, medium or long in order to apply the respective emission factors.

$\mathrm{tCO}_{2}$ e emission $=$ distance travelled $\times$ emission factor

Table 7

Emission factors.

\begin{tabular}{|c|c|c|c|c|}
\hline Vehicle/Fuel & & & & Source \\
\hline \multicolumn{5}{|c|}{ Emission factors for employee and business travel } \\
\hline \multirow[t]{3}{*}{ Car/Alcohol } & & 0.11780 & $\mathrm{~kg} \mathrm{CO} / 2 / \mathrm{km}$ & $\operatorname{MMA}\left(\mathrm{CO}_{2}\right) / \mathrm{MCT}\left(\mathrm{CH}_{4}, \mathrm{~N}_{2} \mathrm{O}\right)$ \\
\hline & & 0.00001 & $\mathrm{~kg} \mathrm{CH} / 4 / \mathrm{km}$ & \\
\hline & & 0.000004 & $\mathrm{~kg} \mathrm{~N}_{2} \mathrm{O} / \mathrm{km}$ & \\
\hline \multirow[t]{3}{*}{ Car/Gasoline } & & 0.22690 & $\mathrm{~kg} \mathrm{CO} / 2 / \mathrm{km}$ & $\operatorname{MMA}\left(\mathrm{CO}_{2}\right) / \mathrm{MCT}\left(\mathrm{CH}_{4}, \mathrm{~N}_{2} \mathrm{O}\right)$ \\
\hline & & 0.00001 & $\mathrm{~kg} \mathrm{CH}_{4} / \mathrm{km}$ & \\
\hline & & 0.00001 & $\mathrm{~kg} \mathrm{~N}_{2} \mathrm{O} / \mathrm{km}$ & \\
\hline \multirow[t]{3}{*}{ Motorbike/Gasoline } & & 0.22690 & $\mathrm{~kg} \mathrm{CO}_{2} / \mathrm{km}$ & $\operatorname{MMA}\left(\mathrm{CO}_{2}, \mathrm{CH}_{4}\right)$ \\
\hline & & 0.00012 & $\mathrm{~kg} \mathrm{CH} / 4 / \mathrm{km}$ & \\
\hline & & - & $\mathrm{kg} \mathrm{N}_{2} \mathrm{O} / \mathrm{km}$ & \\
\hline \multirow[t]{3}{*}{ Bus/Diesel } & & 0.2671 & $\mathrm{~kg} \mathrm{CO}_{2} / \mathrm{km}$ & $\operatorname{MMA}\left(\mathrm{CO}_{2}\right) / \mathrm{MCT}\left(\mathrm{CH}_{4}, \mathrm{~N}_{2} \mathrm{O}\right)$ \\
\hline & & 0.00002 & $\mathrm{~kg} \mathrm{CH} / \mathrm{km}$ & \\
\hline & & - & $\mathrm{kg} \mathrm{N} 2 \mathrm{O} / \mathrm{km}$ & \\
\hline \multicolumn{5}{|l|}{ Emissions factors for type of fuel } \\
\hline \multirow[t]{3}{*}{ Gasoline } & & 2.2690 & $\mathrm{~kg} \mathrm{CO} / \mathrm{l}$ & $\operatorname{MMA}\left(\mathrm{CO}_{2}\right) / \mathrm{IPCC}\left(\mathrm{CH}_{4}, \mathrm{~N}_{2} \mathrm{O}\right)$ \\
\hline & & 0.0008 & $\mathrm{~kg} \mathrm{CH} / \mathrm{l}$ & \\
\hline & & 0.00026 & $\mathrm{~kg} \mathrm{~N}_{2} \mathrm{O} / \mathrm{l}$ & \\
\hline \multirow[t]{3}{*}{ Diesel } & & 2.6710 & $\mathrm{~kg} \mathrm{CO} / \mathrm{l}$ & $\operatorname{MMA}\left(\mathrm{CO}_{2}\right) / \mathrm{IPCC}\left(\mathrm{CH}_{4}, \mathrm{~N}_{2} \mathrm{O}\right)$ \\
\hline & & 0.0001 & $\mathrm{~kg} \mathrm{CH} / 4$ & \\
\hline & & 0.00014 & $\mathrm{~kg} \mathrm{~N}_{2} \mathrm{O} / \mathrm{l}$ & \\
\hline \multirow[t]{3}{*}{ Alcohol } & & 1.1780 & $\mathrm{~kg} \mathrm{CO} / \mathrm{l}$ & MMA $\left(\mathrm{CO}_{2}\right) / \mathrm{IPCC}\left(\mathrm{CH}_{4}\right)(2006)$ \\
\hline & & 0.0004 & $\mathrm{~kg} \mathrm{CH}_{4} / \mathrm{l}$ & \\
\hline & & - & $\mathrm{kg} \mathrm{N}_{2} \mathrm{O} / \mathrm{l}$ & \\
\hline \multicolumn{5}{|l|}{ Emissions factors for air travel } \\
\hline Aereal distance & Increased to reflect the real route & & & \\
\hline \multirow[t]{3}{*}{ Long distance $(\mathrm{d} \geq 3700 \mathrm{~km})$} & $9 \%$ & 0.1106 & $\mathrm{~kg} \mathrm{CO}_{2} /$ passanger*km & DEFRA $\left(\mathrm{CO}_{2}\right) /(\mathrm{EPA}, 2007)\left(\mathrm{CH}_{4}, \mathrm{~N}_{2} \mathrm{O}\right)$ \\
\hline & & 0.00006 & $\mathrm{~kg} \mathrm{CH}_{4} /$ passanger* $\mathrm{km}$ & \\
\hline & & 0.000002 & $\mathrm{~kg} \mathrm{~N}_{2} \mathrm{O} /$ passanger*km & \\
\hline \multirow[t]{3}{*}{ Average distance $(500 \leq \mathrm{d}<3700 \mathrm{~km})$} & $9 \%$ & 0.0983 & $\mathrm{~kg} \mathrm{CO}_{2} /$ passanger* $\mathrm{km}$ & DEFRA $\left(\mathrm{CO}_{2}\right) /(\mathrm{EPA}, 2007)\left(\mathrm{CH}_{4}, \mathrm{~N}_{2} \mathrm{O}\right)$ \\
\hline & & 0.00006 & $\mathrm{~kg} \mathrm{CH}_{4} /$ passanger*km & \\
\hline & & 0.000002 & $\mathrm{~kg} \mathrm{~N}_{2} \mathrm{O} /$ passanger* $\mathrm{km}$ & \\
\hline \multirow[t]{3}{*}{ Short distance $(\mathrm{d}<500)$} & $9 \%$ & 0.1753 & $\mathrm{~kg} \mathrm{CO}_{2} /$ passanger*km & DEFRA $\left(\mathrm{CO}_{2}\right) /(\mathrm{EPA}, 2007)\left(\mathrm{CH}_{4}, \mathrm{~N}_{2} \mathrm{O}\right)$ \\
\hline & & 0.00012 & $\mathrm{~kg} \mathrm{CH}_{4} /$ passanger* $\mathrm{km}$ & \\
\hline & & 0.000004 & $\mathrm{~kg} \mathrm{~N}_{2} \mathrm{O} /$ passanger* ${ }^{*} \mathrm{~m}$ & \\
\hline
\end{tabular}


where,

Distance travelled: estimated annual distance (either air or land travel);

Emission factors used in this study for air transport are based on the guidelines for Defra/DECC's Greenhouse Gas Conversion Factors for Company Reporting (Defra/DECC, 2012) and those for car passengers are based on the national inventory for road vehicles prepared by the Ministry of the Environment in Brazil (MMA, 2011).

Employee commuting - This concept corresponds to the distance covered during the house to work commute for each employee throughout the year. Emissions from employee commutes were estimated as follows:

\section{Emissions from employee commutes $\mathrm{tCO}_{2} \mathrm{eq}$ \\ $=$ distance travelled $\times$ emission factor}

Specific procedures were followed to estimate the distance travelled by employees as Embasa does not collect information regarding the route taken by its employees from their homes to work, nor does the company hold data regarding the type of transport and fuel used. Embasa registers the location of the home, the number of employees per business unit and if the employee receives transport benefits on its employee database. Embasa supplied data for 5765 registered employees through its Personnel Management Department, divided between the metropolitan region and the countryside. As the information provided was not sufficient for any calculations (no data on distance travelled and form of transport used), the following criteria was adopted:

1) employees who receive transport benefits: everyone uses the bus

2) employees who do not receive transport assistance in two groups:

Salvador and MRS (70\% use cars, 30\% use motorbikes)

Regional units (60\% use cars, 30\% use motorcycles and 10\% bicycles or walk)

It was considered that cars and motorcycles run on gasoline, as the cost of alcohol in 2012 not was not advantageous; however, this assumption considers the worst emission setting.

Metropolitan area.-The route from the neighborhood in which the employee lives to the workplace was traced using Google Map, in order to estimate the distance travelled. For cases in which Google Maps provided two different routes, the longest one was used. It was considered that an employee commutes from house to work once a day, on 250 days, the number of working days per year. Therefore:
Regional units.-The data provided by Embasa's Personnel Management Department was used to calculate the GHG emissions for the 3073 employees from the business units outside the metropolitan area. The travel distance for each employee was calculated with Google Maps based on his/her home address and his/her respective workplace. As for the Metropolitan region, it was considered that an employee commuted once a day on 250 working days per year.

It should be emphasized that it was not possible to locate all of the addresses of Embasa's town offices or all of the employees' home addresses. In such cases an average distance was applied on the basis of those actually found. For the situations in which it was not possible to locate any of the addresses, it was considered that the employee's home address was in the city/town center and his work unit was the local office, thereby adopting the distance of $1 \mathrm{~km}$. In all of the cases in which an employee lived in the city/town center, the Municipal Town Hall was adopted as the reference point for his home address.

Table 6 shows the distribution of employees that use their own means of transport to get to work in the countryside units.

The emission factors used for passenger transport are based on the national inventory of land vehicles prepared by the Ministry of the Environment in Brazil (MMA, 2011) and Second National Communication in Brazil (Ministry of Science and Technology of Brazil, 2010). Table 7 shows the emissions factor for type of fuel, for employee and business travel.

\section{Results and discussion}

The total GHG emissions of Embasa obtained with the above method are summarized in Fig. 2 and Table 8:

Scope 1. Wastewater management - The methane emissions from this activity came to a total of $865,462.92 \mathrm{tCO}_{2} \mathrm{eq}$, constituting the most significant source (about 90\%) of emissions among those analyzed. The removal of BOD by the sewage (anaerobic) treatment plants was responsible for the emission of $448,858.84 \mathrm{tCO}_{2} \mathrm{eq} /$ year, while the emissions from the untreated BOD that passed through the facilities and was discharged to the environment corresponded to $46,749.70 \mathrm{tCO}_{2}$ eq. The emissions corresponding to the BOD which does not enter a treatment system was by far the highest in Scope 1: 369,818.38 tCO tCq. .

Gupta and Singh (2012) working with sewage treatment plants, found a more representative value for emissions in scope 2 (2863 $\mathrm{tCO}_{2} \mathrm{eq}$ in a total of $3027.84 \mathrm{tCO}_{2} \mathrm{eq}$ ), which refers to electricity consumption at the facilities. The main difference between the two studies is that these authors considered aerobic treatment

Distance travelled $=$ Distance from the neighborhood to the company $($ obtained from Google Maps $) \times 2 \times 250$

In the case of employees using cars, a 15\% increase in their commuting was considered in order to account for those employees who go home for lunch.

A more detailed analysis was carried out for the routes of 2692 employees in the Metropolitan Region of Salvador. The total for these journeys was $17,106,550 \mathrm{~km}$. This was divided between employees who receive travel benefits $(1,641$, with $10,738,550 \mathrm{~km})$ and therefore use the bus, and those who do not (1051 with $6,368,000 \mathrm{~km}$ ). Table 5 summarizes the commuting data for the metropolitan area. plants and Embasa uses mainly anaerobic processes with no biogas burning. Therefore, in the first case, there is a lower production of methane but higher energy consumption. Moreover, the electricity mix in the Brazil is mainly clean (84.5\% was hydroelectricity in 2012). This is one of the reasons why the emission of BOD removed by the plants was similar to the emission of BOD which is not removed. Table 9 shows the results.

Direct mobile combustion - The sanitation company consumed approximately 1,449,433 L of diesel, 647,960 L of gasoline, and 431,967 L of alcohol in 2012. The associated emissions 


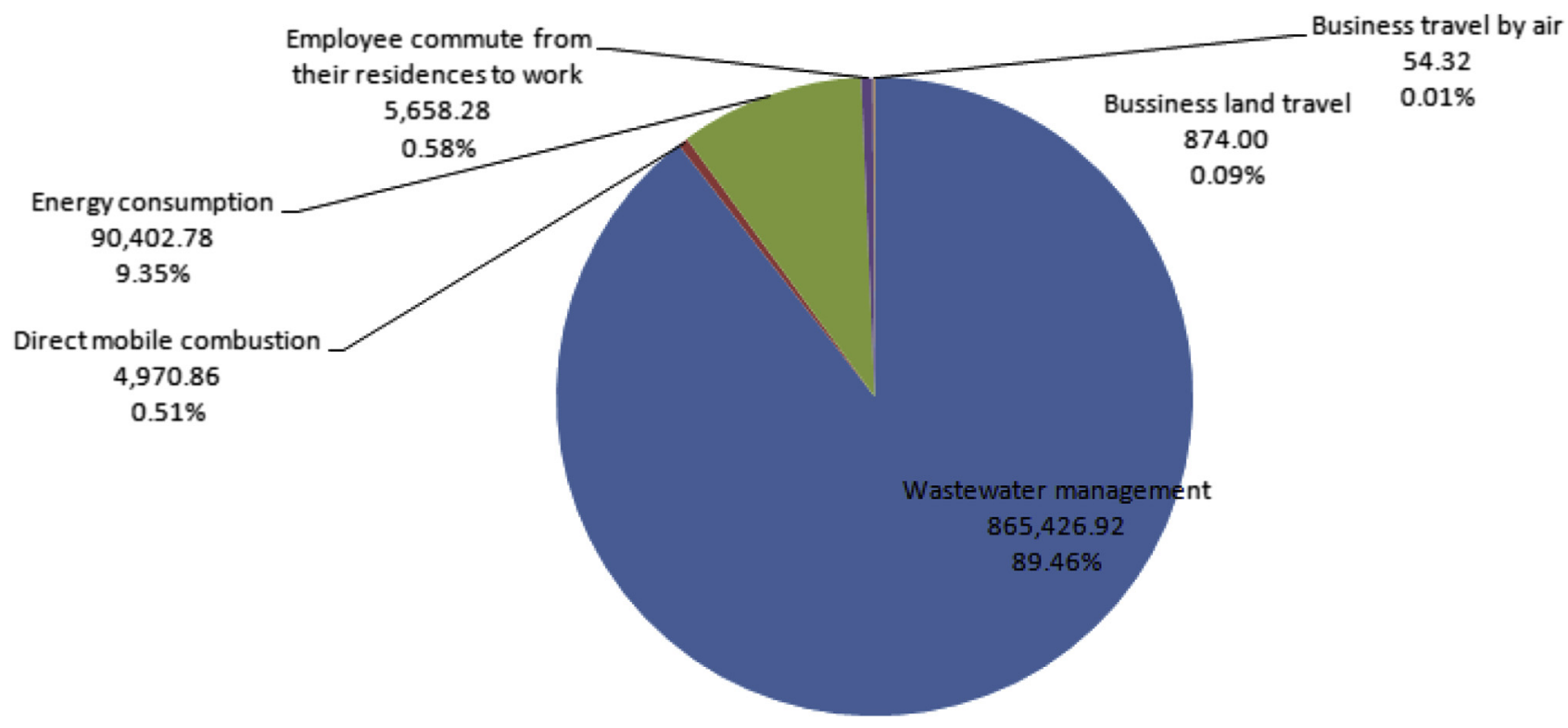

Fig. 2. Emissions results.

were $3741.00 \mathrm{tCO}_{2} \mathrm{eq}, 1226.37 \mathrm{tCO}_{2} \mathrm{eq}$ and $3.48 \mathrm{tCO}_{2} \mathrm{eq}$ respectively, producing a total of $4970.86 \mathrm{tCO}_{2} \mathrm{eq}$.

It is suggested that the company began to gradually use a larger quantity of alcohol, with the aim of reducing diesel emissions. An additional option especially in the metropolitan area may be a carpooling program.

Scope 2. Energy consumption - The total emissions resulting from electrical energy consumption was $90,402.78 \mathrm{tCO}_{2}$ eq/year. Of the total emissions relating to energy consumption, $89.62 \%$ refers to water supply, $9.6 \%$ to wastewater and $0.74 \%$ for administrative activities. Thus, the company should adopt energy efficiency measures in order to reduce consumption associated to these activities and, consequently, indirect emissions in scope 2 .

Scope 3. Business travel - Trips made by air were divided into short, medium and long distances, in order to apply the proper emission factor. The resulting emissions were $0.662,49.54$ and $4.12 \mathrm{tCO}_{2} \mathrm{eq}$ respectively and $54.32 \mathrm{tCO}_{2} \mathrm{eq}$ as total emissions.

Regarding land travel, 5765 business trips accounted for a total of $3,796,748 \mathrm{~km}$ covered during 2012. The emission factors for two different fuels were used in order to obtain the highest value. If a car fueled by alcohol is considered the emissions are $452.8 \mathrm{tCO}_{2} \mathrm{eq}$.

Therefore, it was assumed that all of the journeys were made by cars using gasoline, so $874 \mathrm{tCO}_{2} \mathrm{eq}$, were produced.

Information regarding the type of vehicle used by employees for business land trips was not available. Generally, they are carried out using rental cars which are under the company's control. However, they may also be made by bus. We maintained the emission as scope 3, as the calculation related to business trips was lower than expected. Embasa has a significant number of service providers who work at their installations but control of their daily costs for business travel is dispersed throughout the human resource management for the various service providers. Therefore, a survey of the number of trips made by these workers was not possible, constituting a limitation to this study.

In order to improve the calculations for business trips, Embasa needs to create a database containing information on trips, such as the route and means of transport used. The service providers also need to report this information, which should also be entered into this database.

Employee commuting - The total emissions as a result of employees travelling within the metropolitan region was $4432.71 \mathrm{tCO}_{2} \mathrm{eq}$. The emissions for commuting in the countryside were $1225.57 \mathrm{tCO}_{2} \mathrm{eq}$.

As per the business trips, the emissions in this category were lower than the actual figures, considering that the personnel from the service companies were not included. To improve the inventory, it is suggested that the company gathers data on its service suppliers. As proposed for business trips, it is recommended that a database is created containing information on the employee's home address and the form of transport used. The transport information may be obtained by inserting this into the employee record controlled by the Personnel Management Department.

According to the Ministry of Science, Technology and Innovation (MCTI, 2013), Brazil emitted 1,246,677 Gg CO 2 eq in 2010, with the waste sector being responsible for $4 \%$ of the country's total emissions. Despite this sector's low percentage within the country's emission profile, it was confirmed that emissions increased by $16.4 \%$ between 2005 and 2010. There was a 6.2\% increase in sewage treatment in particular. Brazil emitted $9030 \mathrm{Gg} \mathrm{CO}_{2} \mathrm{eq}$ ) in 2010. With sewage coverage in Brazil reaching only 64.3\% (Brazilian Institute of Geography and Statistics - IBGE, 2013), an increase in

Table 9

Emission Factor and carbon emissions from wastewater.

\begin{tabular}{|c|c|c|c|}
\hline Category & Emissions factors $\left(\mathrm{kg} \mathrm{CH}_{4} / \mathrm{kg} \mathrm{BOD}\right)$ & Methane emissions ( $\mathrm{t} \mathrm{CH}_{4} /$ year) & Carbon emissions ( $\mathrm{t} \mathrm{CO}_{2} \mathrm{eq} /$ year) \\
\hline BOD Removed & 0.0950 & $21,374.23$ & $488,858.84$ \\
\hline BOD discharged & 0.0782 & $17,610.39$ & $369,818.38$ \\
\hline BOD not removed & 0.0098 & 2226.18 & $46,749.70$ \\
\hline Total & & & $865,426.92$ \\
\hline
\end{tabular}


emissions may take place depending on the technological option selected to treat this waste. 15 countries in the EU (Austria, Belgium, Denmark, Finland, France, Germany, Greece, Ireland, Italy, Luxembourg, Netherlands, Portugal, Spain, Sweden and the United Kingdom) emitted $4999 \mathrm{Gg} \mathrm{CO} \mathrm{CO}_{2} \mathrm{eq}$ relating to methane from wastewater treatment (EEA, 2014) in 2012. Thus, the importance of Brazilian companies preparing greenhouse gas inventories and outlining strategies to reduce emissions is confirmed. A reference to SABESP is pertinent in this case. This is the largest sanitation company in Brazil, serving a population of 24.2 million, including $59 \%$ of the city of São Paulo, which is the most populous city in the country. SABESP emitted 1,163,054 t $\mathrm{CO}_{2}$ eq related to wastewater treatment systems, 57,327.99 t $\mathrm{CO}_{2} \mathrm{eq}$ linked to discharge and wastewater collected and untreated and $110,968.94$ t $\mathrm{CO}_{2} \mathrm{eq}$ on indirect energy emissions (SABESP, 2013) in 2010. With regards to COPASA, which is the second largest sanitation company in Brazil, which serves 14 million people and is equivalent to $78 \%$ of the population in the State of Minas Gerais, it emitted 437,226.60 t $\mathrm{CO}_{2} \mathrm{eq}$ related to methane emissions and 55,033.96 $\mathrm{t} \mathrm{CO}_{2} \mathrm{eq}$ on energy emissions (COPASA, 2013) during 2012. Embasa produced methane and energy emissions which were higher than those of COPASA. The high level of Embasa's emissions for wastewater treatment is related to a higher proportion of anaerobic treatment technologies, without burning methane or making use of it. COPASA, for example, is more advanced in this area, having reduced emissions by 13,713 t $\mathrm{CO}_{2}$ eq through using biogas. Embasa, one of the largest sanitation companies in Brazil, therefore has great scope to review its processes in the search for energy optimization and emission reduction.

\section{Conclusion}

It was found that the emissions resulting from sewage management constitute the largest source of GHG at the sanitation company studied, when considering the scopes defined in this work.

The main difficulty in preparing a GHG emission inventory at the company studied was data collection due to Embasa's extensive area of coverage and the absence of a central information system containing the data necessary to quantify GHG emissions. Furthermore, additional work to incorporate the supply chain (scope 3) into the inventory and an uncertainty analysis is necessary.

A number of actions are recommended in order to reduce GHG emissions at Embasa, based on the results of this study. Biogas capture and reuse in anaerobic reactors and the use of biodiesel (ethanol) for transportation could result in a reduction in GHG generation.

The amount and sources of GHG emissions calculated in this research could support proposals for reduction targets and to carry out benchmarking, which can be achieved through incorporating GHG reduction measures into the company's strategic planning and presenting this in its sustainability report. The results can also help other water companies to implement GHG reduction measures.

\section{Acknowledgements}

The first author thanks CAPES from the Brazilian Government for the scholarship provided and EMBASA for an academic one-year leave. Thanks Aline Coelho Nogueira and Alex Acácio for their technical support.

\section{References}

Alvarez, S., Blanquer, M., Rubio, A., 2014. Carbon footprint using the compound method based on financial accounts. The case of the school of forestry engineering, technical University of Madrid. J. Clean. Prod. 66, 224-232.

Ascui, F., Lovelll, H., 2012. Carbon accounting and the construction of competence. J. Clean. Prod. 36, 48-59.

Barber, W.P.F., 2009. Influence of anaerobic digestion on the carbon footprint of various sewage sludge treatment options. Water Environ. J. 23, 170-179.

Boulos, P.F., Bros, C.M., 2010. Assessing the carbon footprint of water supply and distribution systems. J. Am. Water Works Assoc. 102 (11), 47-54.

Cakir, F.Y., Stenstrom, M.K., 2005. Greenhouse gas production: a comparison between aerobic and anaerobic wastewater treatment technology. Water Res. 39 (17), 4197-4203.

Companhia Ambiental do Estado de São Paulo(CETESB) - Environmental Company of the State of São Paulo São Paulo (State). Board Decision No 254 on August 22, 2012. Regarding criteria for preparing a greenhouse gas inventory in the State of São Paulo and provides other arrangements. Available online: http://www.cetesb.sp. gov.br/userfiles/file/mudancasclimaticas/proclima/file/legislacao/estado_sp/ decreto/decisao_de_diretoria_254_2012.pdf. (accessed October 10.10.13.).

COPASA, 2013. Investor Carbon Disclousure Project Information Request. Available online. www.cdp.net (accessed: 20.09.14.).

Daelman, M.R., van Voorthuizen, E.M., van Dongen, L.G., Volcke, E.I., van Loosdrecht, M.C., 2013. Methane and nitrous oxide emissions from municipal wastewater treatment - results from a long-term study. Water Sci. Technol. 67 (10), 2350-2355.

Department of the Environment, Food and Rural Affairs and Department of Energy and Climate Change (Defra/DECC), 2012. Guidelines to Defra/DECC's GHG Conversion Factors for Company Reporting, Version 1.1.AEA. Defra, DECC, UK. Available online. http://www.defra.gov.uk/publications/files/pb13773-ghg-conversion-factors-2012.pdf (accessed March 03.03.13.).

EEA. European Environment Agency, 2014. Annual European Union Greenhouse Gas Inventory 1990-2012 and Inventory Report. Available online. http://www.eea. europa.eu/publications/lrtap-2014 (accessed 20.09.14.).

EMBASA-Empresa Baiana de Águas e Saneamento S.A, 2012. Management Report Executing Plans and Programs - 2012 Financial Year. Salvador.

EPA. United State Environmental Protection Agency, 2007. Inventory of U.S. Greenhouse Gas Emissions and Sinks: 1990-2005. United States.

Federal Law $\mathrm{N}^{\circ} 12.187$ of December 29, 2009. It covers the National Policy for Climate Change. Official Federal Journal.

Figueiredo, M.C.B., Kroeze, C., Potting, J., Barros, V.S., Aragão, F.A.S., Gondim, R.S., Santos, T.L., Boer, I.J.M., 2013. The carbon footprint of exported Brazilian yellow melon. J. Clean. Prod. 47, 404-414.

Foley, J., Yuan, Z., Lant, P., 2009. Dissolved methane in rising main sewer systems: field measurements and simple model development for estimating greenhouse gas emissions. Water Sci. Technol. 60 (11), 2963-2971.

Foley, J., Haas, D., Yuan, Z., Lant, P., 2010. Nitrous oxide generation in full-scale biological nutrient removal wastewater treatment plants. Water Res. 44, $831-844$.

Frijns, J., 2011. Towards a common carbon footprint assessment methodology for the water sector. Water Environ. J. 26, 63-69.

Galli, A., Wiedmann, T., Ercin, E., Knoblauch, D., Ewing, B., Giljum, S., 2012. Integrating ecological, carbon and water footprints into a "Footprint Family" of indicators: definition and role in tracking human pressure on the planet. EcologicalIndicators 16, 100-112.

GHG Protocol, 2010. The Greenhouse Gas Protocol Brazilian Program. Avalaible online. http://www.ghgprotocolbrasil.com.br/ (accessed 14..04.14.).

Girondolli, L.M., 2009. Projeto Carbono Neutro. Companhia Espírito Santense de Saneamento -CESAN. Available online. http://www.cesan.com.br/e107_files/ downloads/0-seminario-meio-ambiente-programa_carbono_neutro_-_ludimila_girondoli.pdf (accessed 10.12.13.)

Güereca, L.P., Torres, N., Noyola, A., 2013. The carbon footprint as a basis for a cleaner research institute in Mexico. J. Clean. Prod. 47, 396-403.

Guisasola, A., Haas, D., Keller, J., Yuan, Z., 2008. Methane formation in sewer systems. Water Res. 42, 1421-1430.

Guisasola, A., Sharma, K.R., Keller, J., Yuan, Z., 2009. Development of a model for assessing methane formation in rising main sewers. Water Res. 43, 2874-2884.

Gupta, D., Singh, S.K., 2012. Greenhouse gas emissions from wastewater treatment plants: a case study in Noida. J. Water Sustain. 2 (2), 131-139.

Hertwich, E.G., Peters, G.P., 2009. The carbon footprint of nations: a global, tradelinked analysis. Environ. Sci. Technol. 43 (16), 6414-6420.

IBGE. Brazilian Institute of Geography and Statistics, 2013. Pesquisa Nacional por amostra de domicilios (PNAD). Available online. http://www.ibge.gov.br/home estatistica/pesquisas/pesquisa_resultados.php?id_pesquisa $=40 \quad$ (accessed 20.09.14.).

IPCC, 2006. Intergovernmental panel on climate change. In: Eggleston, H.S., Buendia, L., Miwa, K., Ngara, T., Tanabe, K. (Eds.), National Greenhouse Gas Inventory Programme. IPCC Guidelines for National Greenhouse Gas Inventories. IGES, Hayama, Japan, 2006. Available online. http://www.ipcc-nggip.iges.or.jp/ public/2006gl/pdf/0_Overview/V0_0_Cover.pdf (accessed 17.03.13.).

ISO, 2006. ISO 14064-the Greenhouse Gas. International Organization for Standartization, Geneva, Switezerland. 
Klein-Banai, C., Theis, T.L., 2013. Quantitative analysis of factors affecting greenhouse gas emissions at institutions of higher education. J. Clean. Prod. 48, 29-38.

Larsen, H.N., Hertwich, E.G., 2010. Implementing carbon-footprint-based calculation tools in municipal greenhouse gas inventories. J. Ind. Ecol. 14 (6), 965-977.

Larsen, H.N., Pettersen, J., Solli, C., Hertwich, E.G., 2013. Investigating the carbon footprint of a University and the case of NTNU. J. Clean. Prod. 48, 39-47.

Law, Y., Ye, L., Pan, Y., Yuan, Z., 2012. Nitrous oxide emissions from wastewater treatment processes. Phil. Trans. R. Soc. B 367 (1593), 1265-1277.

Li, X., Hongwei, T., Rackes, A., 2015. Carbon footprint analysis of student behavior for a sustainable university campus in China. J. Clean. Prod. 1-12.

Ministry of Science and Technology and Innovation of Brazil, 2013. Annual Estimates of Greenhouse Emissions in Brazil. MCTI, Brasília.

Ministry of Science and Technology of Brazil, 2010. Second National Communication in Brazil to the United Nations Convention on Climate Change. MCT, Brasília.

Ministry of Science and Technology of Brazil, 2012. Factor of Energy Emission.

Ministry of the Environment, 2011. 1st National Inventory of Atmospheric Emissions by Road Vehicles. Brazil.

Ozawa-Meida, L., Brockway, P., Letten, K., Davies, J., Fleming, P., 2013. Measuring carbon performance in a UK University through a consumption-based carbon footprint: De Montfort University case study. J. Clean. Prod. 56 (1), 185-198.

Penman, Gytarsky, Hiraishi, 2006. Intergovernmental Panel on Climate Change. Guidelines for National Greenhouse Gas Inventories, vol. 5. Waste.

Perini, D.S., 2011. Estratégias de adaptação e mitigação das emissões de gases de efeito estufa: o caso CAGECE. Master's Thesis. Professional Master's qualification in Administration and Controllership at the Federal University of Ceará, Fortaleza.

Rennó, C.R.A., 2011. Inventário de emissões de gases do efeito estufa - GEE para avaliação da atuação ambiental da COPASA. In: $26^{\circ}$ Congresso Brasileiro de Engenharia Sanitária e Ambiental. Porto Alegre/RS.

SABESP, 2007. Inventory of greenhouse gas emissions - GEE. Sabesp: base year 2007. In: 1st State Seminar on Climate Change and Sanitation 2009. Available online. http://site.sabesp.com.br/uploads/file/sociedade meioamb/Confer\%C3\% AAncias\%20de\%20Gest\%C3\%A30\%20Ambiental/Invent\%C3\%A1rio\%20sobre\% 20Emiss\%C3\%A30\%20de\%20Gases\%20Poluentes\%20_Darcy\%20Brega\%20Sabesp. pdf (accessed 18.09.13.)
SABESP, 2013. Investor Carbon Disclousure Project Information Request. Available online. www.cdp.net (accessed 20.09.14.)

SANEPAR, 2010. Inventor of Greenhouse Gas Emissions. Brazilian GHG Program Protocol, 2009. Available online. http://www.ghgprotocolbrasil.com.br/cms/ arquivos/sanepar_2009_aprovado_selo.pdf (accessed 15.04.13.).

Schaltegger, S., Csutora, M., 2012. Carbon accounting for sustainability and management. Status quo and challenges. J. Clean. Prod. 36, 1-16.

Shahabadi, M.B., Yerushalmi, L., Haghighat, F., 2009. Impact of process design on greenhouse gas (GHG) generation by wastewater treatment plants. Water Res. 43 (10), 2679-2687.

State Institute for the Environment (INEA). Rio de Janeiro (State). Resolution No 64 dated December, 12, 2012: Regarding the presentation of a Greenhouse Gas Inventory to acquire an environment permit in the State of Rio de Janeiro. Available online: http://www.cetesb.sp.gov.br/userfiles/file/ mudancasclimaticas/proclima/file/legislacao/estadual/rio_de_janeiro/ resolucao/Resolucao ineia_n64_rj.pdf. (accessed 13.10.13.).

Stechemesser, K., Guenther, E., 2012. Carbon accounting: a systematic literature review. J. Clean. Prod. 36, 17-38.

Uggetti, E., Garcia, J., Lind, S.E., Martikainen, P.J., Ferrer, J., 2012. Quantification of greenhouse gas emissions from sludge treatment wetlands. Water Res. 46 (6), 1755-1762.

Vázquez-Row, I., Rugani, B., Benetto, E., 2013. Tapping carbon footprint variations in the European wine sector. J. Clean. Prod. 43, 146-155.

Wang, J., Zhang, Xie, H., Oi, P., Ren, Y., Hu, Z., 2011. Methane emissions from a fullscale A/A/O wastewater treatment plant. Bioresour. Technol. 102, 5479-5485.

Wiedmann, T., Wood, R., Minx, J.C., Lenzen, M., Guan, D.B., Harris, R., 2010. A carbon footprint time series of the UK - results from a multi-region input-output model. Econ. Syst. Res. 22 (1), 19-42.

WRI/WBCSD and World Resources Institute and World Business Council for Sustainable Development, 2004. The Greenhouse Gas Protocol: a Corporate Accounting and Reporting Standard (Revised Edition). The Greenhouse Gas Protocol Initiative, USA and Switzerland.

Zakkour, P., Kemper, J., Dixon, T., 2014. Incentivising and accounting for negative emission technologies. Energy Procedia 63, 6824-6833.

Zhai, Q., Cao, H., Zhao, X., Yuan, C., 2014. Assessing application potential of clean energy supply for greenhouse gas emission mitigation: a case study on general motors global manufacturing. J. Clean. Prod. 75, 11-19. 